\title{
Blood to cerebrospinal fluid barrier in spontaneous hypertension and ventricular dilation
}

Agustin Castañeyra-Perdomo*1,2, Ibrahim González-Marrero², Paloma Fernández-Rodríguez ${ }^{2}$, Juan M Gonzalez-Toledo ${ }^{1}$, Leandro Castañeyra-Ruiz' ${ }^{2}$, Maria E Segui ${ }^{2}$, Agustin Castañeyra-Ruiz², Hector de Paz-Carmona ${ }^{1}$, Isabel Hernandez-Garde ${ }^{1}$ and Emilia M CarmonaCalero ${ }^{1,2}$ \author{
Instituto de Investigación y Ciencias de Puerto del Rosario, Fuerteventura, Spain \\ Email: Agustin Castañeyra-Perdomo* - acastane@ull.es \\ * Corresponding author \\ from 52nd Annual Meeting of the Society for Research into Hydrocephalus and Spina Bifida \\ Providence, RI, USA. II-14 June 2008 \\ Published: 3 February 2009 \\ Cerebrospinal Fluid Research 2009, 6(SuppI I):S6 doi:10.1 186/1743-8454-6-SI-S6
}

Address: ${ }^{1}$ Departamento de Anatomía, Facultad de Medicina, Universidad de La Laguna, Tenerife, Spain and ${ }^{2}$ Departamento de Biotecnología,

This abstract is available from: http://www.cerebrospinalfluidresearch.com/content/6/SI/S6

(C) 2009 Castañeyra-Perdomo et al; licensee BioMed Central Ltd.

\section{Background}

Arterial hypertension produces ventricular dilation, CSF protein composition variations as well as alterations in the circumventricular organ and choroid plexus (CP). Cerebrospinal fluid (CSF) has an important relationship with the blood and the brain, and encephalic pathology could alter the connections between the blood, brain and CSF, and consequently the protein composition of the CSF. Furthermore, certain proteins could be used as markers such as transthyretin and S-100 $\beta$, which are extravasated when central nervous system (CNS) barriers are breached. The S- $100 \beta$ is primarily synthesized in the brain by the astrocytes and is released into the blood when the blood brain barrier (BBB) is disrupted. Transthyretin is a protein primarily located in the brain in choroid plexus (CP), subcommissural organ (SCO) and, as soluble monomer, in the CSF, where it has a positive gradient for extravasation in peripheral blood, when the blood to CSF barrier (BCB) is altered. The aim of the present work is to analyze the CNS barriers in the arterial hypertension using antibodies against S-100 $\beta$, transthyretin monomer (TTRm), TA-p73 and Reissner fibre (AFRU).

\section{Materials and methods}

Brain, cerebrospinal fluid and serum were extracted from control Wistar-Kioto (WKY) rats and spontaneously hypertensive rats (SHR) of 10 months of age. Brain sections containing the SCO and the CP were processed by immunohistochemistry using the following as primary antibodies: anti-S-100 $\beta$, anti-TTRm anti-TA-p73 and AFRU. Western blot and 2-D electrophoresis of CSF, serum and extracts of SCO and CP were performed.

\section{Results}

We have observed that the expression different antibodies varied with the hypertension, thus TTRm in control rats was clearly observed in the CP and scarcely observed in the SCO, but the TTRm in SHR increased in the CP and is clearly positive in the SCO. In both groups only the S$100 \beta$ - was present in the CP. TAp73-ir was lower in the SCO and CP of SHR with respect to WKY rats and AFRUir was also lower in SHR rats. Transthyretin was higher in serum in the SHR with respect to WKY rats. However, in the CSF the transthyretin was lower in the SHR compared to WKY rats and contrarily S- $100 \beta$ was higher SHR compared to WKY rats. 


\section{Conclusion}

Hypertension in these rats produces an increase of transthyretin in serum and a decrease in cerebrospinal fluid; we conclude that hypertension could produce a disruption in the blood to CSF barrier that allows extravasation from CSF to the blood

Publish with Bio Med Central and every scientist can read your work free of charge

"BioMed Central will be the most significant development for disseminating the results of biomedical research in our lifetime. " Sir Paul Nurse, Cancer Research UK

Your research papers will be:

- available free of charge to the entire biomedical community

- peer reviewed and published immediately upon acceptance

- cited in PubMed and archived on PubMed Central

- yours - you keep the copyright 